\title{
Women and Politics Worldwide
}

EDITED BY

BARBARA J. NELSON \& NAJMA CHOWDHURY 
For Mainur Reza Chourdhury

and

Betty-Jane James

and

George Knox
Bernard J. Nelson

and

Rachel Wayne Nelson
Published with assistance from the foundation escalblished in memory of Philip Hamiton Mcillillan of the Class of 1894 , Yale College.

Copyright o 1994 by Yale Unisersiṇ: All rights esserved. This book may not be reproduced, in whole or in part, including illustrations, in any form (beyond that copying permicted by Sections 107 and 108 of the L.S. Copyright Law and excepe by reviewers for the public press), without written permission from the publishers.

Designed by Nancy Ovedovitz. Ser in Galliard sype by The Composing Room of Michigan, Inc. Printed in the United States of America by Edwards Brochers, Ann Arbor, Michigan.

Library of Congress Caraloging-in-Publication Data

Women and politics worldwide / edited by Barbara I. Nelson and . Najma Chowdhury.

p. im.

Includes bibliographical references ( $p$. ) and index. ISs. 0-300-05407-6 (cloch : alk. paper). -

ISs: 0-300-05408-4 (paper : alk. paper)

1. Women in politics-Cross-cultural

studies. 2. Women's rights-Cross-cuitural

studies. 1. Nelson, Barbara J., 1949- .

I1. Caudhuri, Nījamā, 1942- .

HQ1236.IV6363 1994

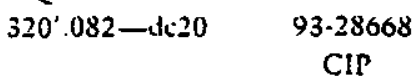

A satalogue record tor this book is available from the British Librarỵ.

The paper in this book meets the guidelines for permanence and durabiling of the Committee on Production Guidelines for Book Longeving of the Council on Library Resources.

$\begin{array}{llllllllll}10 & 9 & 8 & 7 & 6 & 5 & 4 & 3 & 2 & 1\end{array}$ 
PART I

1 $\Delta$ Redefining Politics: Patterns of Women's Political Engagement from a Global Perspecrive NAIMA CHOWDHURY ANO BARBARA I. NELSON WTTH KATHRYN A. CARVER, NANCY J. JOHNSON, AND PAULA L. O'LOUGHLIN

$2 \Delta$ Research Design and Practice: Methodological Issues in Feminist Comparative Politics Research NAIMA CHOWDHURY AND BARBARA I. NELSON WITH NANCY I. JOHNSON AND PACLA L. O'LOLGHLIN

3 A Global Research on Women's Political Engagement: The History of the Women and Politics Worldwide Project NAIALA CHOWDHURY, NANCY I. IOHNSON, BARBARA I. NELSON, AND PACLA L. O'LOUGHLIN

4 $\triangle$ Measuring Women's Status, Portraying Women's Lives: Problems in Collecting Data on Women's Experiences BARBARA I. NELSON WITH KATHRIN A. C.ARVER, PAL'LA L. O'LOUGHLIN, AND WHITNEY THOMIPSON

PART II

$\triangle$ Argentina

From Family Ties to Political Action: Women's Experiences in Argentina MARLA DEL CARMEN FEIJOO

$\triangle$ Australia Locked Out or Locked In? Women and Politics in Australia MARIAN SAWER

$\triangle$ Bangladesh Bangladesh: Gender Issues and Politics in a Patriarchy NAJMA CHOWDHURY 
$\Delta$ Bolivia

Women and Politics: Gender Relations in

Bolivian Political Organizations and

Labor Unions

GLORIA ARDAYA SALINAS

TRANSLATED BY SAMUEL M. DUBOIS

$\Delta$ Brazil

Women in the Struggle for Democracy

and Equal Rights in Brazil

FANNY TABAK

$\Delta$ Canada

Building a Political Voice: Women's Participation and Policy Influence

in Canada

SYIVLA BASHEVKIN

$\Delta$ China

Women's Life in New China

YUE DAIYUN AND LI IIN

A Costa Rica

With Patience and Without Blood:

The Political Struggles of Costa

Rican Women

MIRTA GONZALEZ-SUÁREZ

$\triangle$ Cuba

Revolutionizing Women, Family,

and Power

JEAN STUBBS

A Czechoslovakia (former)

Women's Issues in Czechosiovakia in the

Communist and Postcommunist Periods

SHARON L. WOLCHIK

$\Delta$ Egypt

The Paradoxes of State Feminism

in Egypt

MERVAT F. HATEM

A France

The Same or Different? An Unending

Dilemma for French Women

JANE JENSON AND MARUETTE SINEAU

$\Delta$ Germany

Women and Politics: The New Federal

Republic of Germany

CHRISTLANE LEMKE

(i) Contents
A Ghana

Women and the Evolution of a Ghanaian

Political Synthesis

KAMENE OKONIO

114

Great Britain

The Rules of the Political Game:

Feminism and Politics in Great Britain JONI LOVENDUSKI

$127 \Delta$ Greece

Women Confronting Party Politics

in Greece

ANN R. CACOULLOS

A Hong Kong

142

The Underdeveloped Political Potential of Women in Hong Kong

FANNY M. CHEUNG, SHIRLEY PO-SAN

161 WAN, AND OLIVIA CHI-KIE WAN

- Hungary

Hungarian Women's Political

Participation in the Transition

to Democracy

174 KATAIIN KONCZ

$\Delta$ India

Women's Political Engagement in India: Some Critical Issues

HEM LATA SWARUP, NIROJ SINHA, CHITRA GHOSH, AND PAM RAJPUT

A Israel

Women and Politics in Israel

DAPHNA SHARFMAN

$\triangle$ Japan

The U.N. Convention on Eliminating

226 Discrimination Against Women and the Status of Women in Japan NUITA YOKO, YAMAGUCHI MITSUKO, AND KUBO KIMIKO

TRANSLATED BY ELIZABETH J. CLARKEE

$\Delta$ Kenya

Man-Made Political Machinery in Kenya: Political Space for Women? 
A Nores, Republic of (South Korea) Homen's Political Engagement and Parriciparion in the Republic of Korea ovsc-sctK sOHN

A Mexico

The Struggle for Life, or Pulling Off the Mlask of Infamy

aU B.ARTRA

TRLSLATED BI JOHN MRAZ

$\triangle$ Moroceo

Wornen in Morocco: Gender Issues and Politics

NCHA .AFIFI AND RAJAE MSEFER

$\triangle$ Nepal

Political Participation of Women in Nepal

MEENA ACHARYA

$\Delta$ The Netherlands

Political Participation of Women:

The Netherlands

MONIQLE LEIIENAAR AND KEES

NIEMOI.LER

A Nigeria

Reversing the Marginalization of the Invisible and Silent Majority: Women in Politics in Nigeria

NASENE OKONJO

$\Delta$. Norwav

The Stare and Women: A Troubled

Relacionship in Norway

IANNEKE VAN DER ROS

$\Delta$ Palestine

Women's Participation in the Palestine Liberation Organization

ALLIL KAWAR

- Papua New Guinea

Rhetoric, Reality, and a Dilemma:

Women and Politics in Papua

New Guinea

EILEEN WORMALD $\triangle$ Peru

Between Confusion and the Law:

Women and Politics in Peru

436

VIRGINIA VARGAS AND

VICTORIA VILLANUEVA

575

$\Delta$ The Philippines

Philippine Feminism in Historical

Perspective

448

BELINDA A. AQUINO

590

$\triangle$ Poland

Polish Women as the Object and Subject of Politics During and After the Communist Period

461 RENATA SIEMIENSSKA

TRANSLATED BY G. DZIURDZIK-

KRASNIEWSKA

608

$\triangle$ Puerto Rico

At the Crossroads: Colonialism and

Feminism in Puerto Rico

YAMILA AZIZE-VARGAS

A South Africa

Women in Politics Under Apartheid:

496 A Challenge to the New South Africa

BARBARA KLUGMAN

$\Delta$ Spain

Women's Political Engagement in Spain

MARIA TERESA GALLEGO MENDEZ

TRANSLATED BY MARGARITA

GOMEZ-REINO

660

$\Delta$ Sudan

The Women's Movement, Displaced

Women, and Rural Women in Sudan

527

MAGDA M. EL-SANOUSI AND NAFISA

AHMED EL-AMIN

674

A Switzerland

Direct Democracy and Women's

Suffrage: Antagonism in Switzerland

REGULA STAMPFI

690

$\Delta$ Turkey

Turkish Women as Agents of Social

Change in a Pluralist Democracy

NERMIN ABADAN-UNAT

560 AND OYA TOKGOZ 
A Union of Soviet Socialist Republics (former)

Soviet Women and Politics: On the Brink of Change

OLGA A. VORONINA

TRANSLATED BY ANATOLII SMIRNOFF

A United Stares

Many Voices But Few Vehicles: The Consequences for Women of Weak Political Infrastructure in the United States

BARBARA J. NELSON AND

KATHRYN A. CARVER
- Uruguay

Uruguay: A Recent History of a Subject with a History of Its Own GRACIELA SARRIZA

TRANSLATED BY INES TRABAL

Appendix: Selected Information from the Country Charts

773

List of Contributors

787

Index

797 


\section{- The Philippines}

POLITICS

Type of Political System: democracy

Sovereignty: republic

Executive-Legislative System: presidential

Type of State: unitary

Type of Party System: multiparty

Major Political Particas

Communist Party of the Philippines-New People's Army (CPP-NPA): Radical underground movement; not a political party in the usual sense:

Moro National Liberation Front (MNLF): Radical underground Muslim movement in Mindanao; founded in 1972.

Laban ng Demokratikong Pilipino (LDP, or Struggle of Democratic Filipinos): Won a majority in the Senate and House of Representatives in the May 1992 elections. Supported Corazon Aquino during her presidency (1987-92).

Partido Demokratikong Pilipino (PDP, or Filipino Democratic Party): Founded by Sen. Aquilino Pimentel. Formed a coalition with some Laban elements to establish PDP-Laban, which fielded Senate candidates in the 1992 elections.

Liberal Party (LP): Founded at independence in 1946. Formed a coalition with the PDP in 1992 to support the presidential candidacy of Sen. Jovito Salonga.

Lakas ng Bayan [People's Power]-National Union of Christian Democrats (Lakas-NUCD): Alliance formed by President Fidel Ramos during his 1992 presidential candidacy.

Nacionalista Party (NP, or Nationalist Party): Oldest major party in the Philippines; formed in 1907 during the U.S. colonial period.

Nationalist People's Coalition (NPC): Alliance arganized by Eduardo Cojuangeo to support his presidential candidacy in 1992.
People's Reform Party (PRP): Alliance organized by Miriam Defensor Santiago to support her presidential candidacy in 1992.

Kilusang Bagong Lipunan (KBL, or New Society Movement): Party created by President Ferdinand Marcos in 1986 while the Philippines was under martial law. Marcos used this party to run in the 1986 snap presidential election against Corazon Aquino. Tear Women Granted Right to Vote: 1937 Year Women Granted Right to Stand for Election: 1937

Percentage of Women in the Legislaturet

Lower House: $8.9 \%$

Upper House: $8.6 \%$

Percentage of Electorate Voting for Highest Elected Office in Most Recent Election (1992): not available

DEMOGRAPHICS

Population: 60,480,000c

Percentage of Population in Urban Areasa

Overall: $42.0 \%$

Female: not available

Male: not available

Percentage of Population Below Age 15:

$39.0 \%=$

Birthrate (per 1,000 population): $35^{f}$

Maternal Mortality Rate (per 100,000 live births): 80

Infant Mortality Rate (per 1,000 live births): 46

Mortality Rate for Cbildren Under Fipe (per 1,000 live births): 75

Average Household Size: 5.68

Mean Age at First Marriage

Female: 22.4

Male: 25.3

Life Expectancy

Female: 63.7

Male: 60.2

EDUCATION

Ratio of Female to Male Enrollment

First-Level Education: 94 
Second-Level Education: 99

Third-Level Education: 119

Literacy Rateh

Female: $82.8 \%$

Male: $83.9 \%$

\section{ECONOMY \\ Gross National Product per Capita: U.S. $\$ 590$}

Percentage of Labor Force in Agriculture: $49.0 \% \mathrm{i}$
Distribution of Agricultural Workers by
Sex

Female: $23.5 \%$

Male: $76.5 \%$

Economically Active Population by Sexd Female: $46.1 \%$

Male: $81.7 \%$

\section{Philippine Feminism in Historical Perspective}

\author{
BELINDAA. AQUINO
}

The Philippines is a tropical archipelago of 7,107 islands-115,781 square miles of territory-on the southeast rim of the Asian continent. Though often considered a small country, the Philippines has a population of 60.7 million, making it the world's 17 th largest nation. The great majority of the people are Roman Catholics (82.1 percent), with the rest divided among Muslims, Protes. tants, Aglipayan (Philippine Independent Church) members, cultural minorities, Iglesia ni Kristo (Church of Christ) members, Buddhists, and others. ${ }^{1}$ A relatively poor country, the Philippines has suffered from a deteriorating economy in recent decades, mostly as a result of large-scale corruption during the regime of Ferdinand Marcos.

Long before the islands were colonized by Spain and then the United States, they had their own cultures, which were shaped by indigenous forces, as well as by Chinese, Arab, and Indian influences. In 1521 the Portuguese explorer Fer- a. Political parties in the Philippines are not formal organizations but loose and shifting coalitions without fixed memberships. Party descriptions are provided by the author.

b. Commission on Elections; 1987 National Election Rasults (Manila).

c. Philippines Country Profile, 1991-1992 (London:

Economist Intelligence Unit, 1991).

d. Asia 1992 Yaarbook(Hong Kong: Far Eastern Economic Review, 1992), 7.

c. National Staristic Yearbook, 1989 (Manila: N2tional Statistics Office, 1990).

f. Ibid.

g. Ibid.

h. Philippine Depelopment Plan for Women, 1989 (Manila: National Commission on the Role of Filipino Women, 1990).

i. Philippine Country Profile, 1991-1992.

j. Integrated Surpay of Households Bulletin, series 56 (Manila: Nacional Staristics Office, First-Fourch Quarters, 1986). dinand Magellan claimed the islands for Spain and named them after King Philip II. Spanish colonial rule-characterized by cruelty toward and repression of the local population by the friars and civil guards-lasted three centuries, not ending until the proclamation of the first Philippine republic in 1898. But after Spain's defeat in the nationalist revolution another colonial power, the United States, formally took possession of the Philippines at the conclusion of the Spanish-American War in 1898.2 Filipino nation. alist forces resisted the new foreign occupation but were overwhelmed by the superior U.S. troops. In August 1898 the U.S. government instituted a military government that lasted until July 1901, when civilian rule was established in areas controlled by the U.S. military. In 1935 the U.S. colonial authorities set up the Philippine Commonwealth with Manuel Luis Quezon as president. 
Commonwealth status was meant to be a transition to the eventual independence of the Philippines, to be granted ten years after the adoption of a constitution and a national election in 1935. But independence was delayed by World War II and the occupation of the country by Japan from 1942 to 1945 . United States forces reoccupied the country in late 1945, and on 4 July 1946 the Philippines won its independence from the United States.

Although it is common to characterize politics in terms of form-liberal democracy, one-party rule, military junta, civil-military coalition, social democracy, theocracy, and so on-these labeis have only analytical convenience and do not capture the political cuiture of a country. Political systems in the Third World are especially difficult to fit into the conceptual models that Western social scientists have developed for political analysis.

In the Philippine case, today's political culture has its roots in the hegemonic system established under Spanish rule and monopolized by an elite class known as the ilustrado (enlightened). This was a small class of landed gentry that controlled the vast majority of the population. Elite rule was essentially continued by the U.S. authorities in spite of their avowed goals of developing democracy and representative government in the colony that they took over from Spain. Formal mechanisms for citizen participation, such as elections and political parties, were formed, and the concepes of due process and checks and bal. ances of governmental authority were introduced. Bur no real changes in the highly unequal social structure and benighted economy took place. Economic policies pursued by the U.S. colonial government-free trade, for instancefavored elires and made them weal thier and more powerful. The elite class also dominated electoral contests and positions.

The continuing influence of the United States in Philippine affairs has been another major fact of political life. The presence of two huge U.S. military bases-Clark Air Base and Subic Naval Base-on Philippine territory has long been the subject of contentious debate between the two countries. Per agreements in 1947 and in subsequent years, the lease on the bases has expired. Negotiations for the termination or continuance of the bases are being conducted, and if a new treaty results from these taiks, it will have to be reviewed and approved by the Philippine Senate.

The Philippines remains basically agricultural, with two-thirds of its population dependent on agriculture, forestry, and fishing for their livelihoods. The industrial sector, which is located principally in the metro-Manila capital region, has not kept pace with the needs of a poor and rapidly expanding population. The economic growth of the country has been hampered by an onerous foreign debe of nearly U.S. \$29 billion, which exacerbates the impoverishment of the people -49 percent are poor according to official estimates, but as many as 70 percent are poor by other estimates. ${ }^{3}$

The political system is anchored in a constitutional democratic form of government, with a president, a bicameral Congress, local governments, a judiciary, and a bureaucracy constituting the basic framework. Except during the nearly 14 years of the Marcos dictatorship, which lasted from Seprember 1972 to February 1986, regular national and local elections have been hetd since independence in 1946. The $202 \mathrm{mem}$ bers of the House of Representatives are elected by district; 18 of them are women. The $23 \mathrm{mem}$ bers of the Senate are elected at large; 2 of them are women. The country is divided into 13 administrative regions, with metro Manila designated the National Capital Region. Each region is composed of a number of provinces and cities.

Prior to the imposition of marcial law in 1972, political power alternated between the $\mathrm{Na}$ cionalista (Nationalist) Party and the Liberal Party. There was little difference in the agendas of the two parties, which were controlled by elite interests. Political candidates opportunistically switched allegiances. Candidates from smaller parties, including those supported by the left, rarely got elected. Though democratic in form, Philippine politics was, and still is, substantially a matter of patronage and privilege.

With the overthrow of the Marcos dictatorship 
in the now-tamous People Power Revolution in 1986, "democratic space" in the country was restored. Corazon C. Aquino, widow of the slain opposition leader Benigno Aquino, Jr., was installed as president. A new constitution was ratified in February 1987, and elections for members of Congress were held three months later. Twenty-two of the winning senators ran as part of Aquino's ruling coalition, which was principally composed of the PDP-Laban (a merger of the Partido Demokratikong Pilipino, or Filipino Democratic Party, and Lakas ng Bayan, or Peopie's Power), the Liberal Party, the United Democratic Nationalist Organization (UNIDO), and other, smaller groups. Only two candidates were elected from groups identified with the opposition.

A communist insurgency led by the Communist Party of the Philippines-New People's Army (CPr-NPA) and Muslim unrest involving the Moro National Liberation Front and other groups pose major problems for the Aquino government. In addition, six coups or attempts at destabilization were either planned or undertaken by disaffected military elements between 1986 and 1989. The most serious of these, the December 1989 coup attempt, nearly toppled the four-year-old Aquino administracion. The military has become politicized in some commands, indicating its dissarisfaction with its traditional subordination to civilian authority. A rise in politically motivated killings and common crimes has also been observed in recent years. At best the post-Marcos period can be characterized as that of a restored but unstable democracy. Marcos's plunder and destruction of the political institurions, as well as Aquino's inability to display decisive leadership, combine to create a climate of insecurity.

\section{WOMEN IN PHILIPPINE SOCIETY}

It is within this context that the historical role of women in Philippine sociery can be examined. Although the evidence is fragmented, instances of what is understood in the Philippines as feminism can be seen as early as the eighteenth cen- tury. The best known of the early Filipina activists is Gabriela Silang of the Ilocos region in the northern Philippines. ${ }^{4}$ She was married to Diego Silang, a rebel leader who was assassinated by a Spaniard in the town of Vigan. Gabriela continued the struggie, setting up a headquarters for the Free Government of the Ilocos in Abra Province to recapture Vigan. When she and her army of 60 entered the town, they were overpowered by Spanish soldiers numbering in the thousands. Gabriela was the last of her group to be hanged in the public square on 20 September 1763.

The political ferment generated by the struggle against Spain opened opportunities for women to go beyond their traditional roles in society. Several women were recruited by the Katipunan-the secret society founded by the revolutionary leader Andres Bonifacio-to enlist mass support against Spanish oppression. Prominent among these women were Melchora Aquino (more popularly known as Tandang Sora, an appellation denoting affection and respect for age), Gregoria de Jesus, Trinidad Tecson, and Marcela Mariño Agoncillo. They came mostly from upper-class families-many of whom had also produced male revolutionaries-buc they had limited education. Other Filipinas worked to advance the cause of education while the Katipunan women were busy in the political struggle. Higher education under the Spanish was open only to sons of the elite. Women were sent to convent schools, where they were taught religion, homemaking, the social graces, and the Victorian code of conduct. The tamous 21 "women of Malolos" defied the laws prohibiting the opening of schools for women by petitioning the governor general to allow the establishment of a school where they could learn Spanish. 5 From the perspective of the women of Malolos, the school was important to the Filipino struggle for equality because the ability to speak Spanish was crucial to educational mobility.

Women's participation in Filipino movements during the Spanish era was not limited to elite women, though evidence to support that view is sketchy. As will be seen later, women from the grass roots, who did not have as much wealth and 
social status as their upper-class counterparts, played a considerable role in shaping the course of Philippine history.

\section{THE STRUGGLE FOR WOMEN'S POLITICAL AND ECONOMIC RIGHTS}

By the time the U.S. colonial regime began, following the establishment of civil government in 1901, a significant core of educated Filipinas had emerged. Nuns had established a normal school for women - the first of its kind in the countryin Naga, in the Bicol region south of Manila, in 1877. Next came the establishment of the Instituto de Mujeres (Women's Institute) in 1900; an exclusive school for giris, the Centro Escolar de Señoritas (now Centro Escolar University), in 1907; and the Philippine Women's University in 1910.6 The founding of the University of the Philippines in 1908 and the transformation of the Philippine Normal School and the University of Santo Tomas into coeducational institutions enabled more women to develop careers, not only in the field of education but also in the various protessions.

The creation of educational opportunities for women was a landmark development. Women's next logical step was to win the right to vore and run for public office; they could not vote or put up candidates in the first national election for the Philippine legislature in 1907, nor were women well represented in the civil service.

Women's realization that they had secondclass status in spite of their increasing sophistication led to the establishment of organizations to fight for women's rights. "Better educated, more articulate, and relatively freed from domestic duties, the women of the middle and upper classes led the wav."7 Elite women also saw the value of organizing and mobilizing support from other women. In time there were a number of women's groups devoted to advancing education, securing better conditions for working women, assisting poor mothers and children, seeking prison reform, and promoting charitable causes and ocher social concerns. The momentum for this organizational activity may be attributed to develop- ments that were put in motion by the arrival of the Americans. Thousands of teachers and missionaries found their way from the United States to the new colony. The colonial government soon realized that "one of the best means to secure the cooperation of the townspeople was through women. . . "8 A prominent U.S. feminist, Carrie Chapman Catt, organized the Women's Club of Manila. The other major women's organizations were the National Federation of Women's Clubs, the Asosacion de Damas Filipinas (Association of Filipino Women), the Catholic Women's Federation, the Women's Medical Association, and a Philippine chapter of the Young Women's Christian Association. The impetus for this explosion of female energy was the "desire of Filipino women for their complete emancipation, political and civil." The women began to respond to opportunities for work beyond the confines of their homes and churches.

The women involved in the suffrage movement came from a broad spectrum of socioeconomic backgrounds, but the leaders were mostly from the upper class - highlyeducated women successful in their professions and active in community affairs. They were often the first women to break through the sex barrier in their chosen professions. ${ }^{10}$ Some were still students at the time, such as Carmen Planas, who was elected the first councilwoman of the city of Manila in the election after female suffrage was granted in 1937. There were none of the class-based, religious, geographic, and other kinds of cleavages that disrupe political movements after a while. The leaders campaigned across the country and were enthusiastically received wherever they went.

Men in the government and the professions vigorousiv opposed women's suffrage. They ridiculed it in the Manila press, calling the suffrage movement a consequence of higher education, which tended to limit the birth rate and thus would depopulate the country. "Women found this strange logic infuriating, but such resistance was typical of the problems that they confronted in their struggle for political enfranchisement, and the adverse male reactions served to unite them in a common cause. 
To appreciate women's struggle to win the rote in the Philippines, it is also important to understand the larger political picture. In the constitution of 1935 the Philippine legislature established the onerous provision that the right of suffrage would be extended to women only if a national plebiscite were held in which no fewer than 300,000 women voted in its favor. This represented roughily one-third of the total number of women eligible to vote on the basis of age and literacy qualifications. ${ }^{12}$ Male suffrage was aiso limited by property (this was later abolished) and literacy requirements, which meant that the great majority of Filipino men could not vote, either. But not one woman could voce. The framers of the constitution, most of whom were opposed to women's suffrage, probably calculated that it would be extremely difficult to meet the 300,000 -vote requirement, especially considering that women would be voting for the first time. They were wrong: 447,725 women vored yes for the amendment in the 1937 plebiscite. The total surpassed the mandated requirement by nearly 150,000 votes! The women themselves were surprised but jubilant about the results of their long struggle.

What accounted for their remarkable achievement? Political organization, as well as persistence and determination. A General Council of Women headquartered in Manila directed the plebiscite campaign, relying on women's clubs in the towns for active support. Club members, in addition to their high social status and high level of education, were experienced in political campaigns and were viewed as strong and influential leaders. ${ }^{13}$ Hundreds of women's club presidents in the provinces gave stirring speeches at carnivals, fairs, and suffrage rallies. Their followers distributed thousands of pamphlets, leaflets, sample ballors, posters, and calendars from feminist leaders. Two women's magazines, Woman's Home Journal and Woman's World, and a radio program featured the suffrage issue. Students were mobilized as well.

Women leaders also relied on their personal networks. For instance, one of the foremost feminists, Pilar Hidalgo Lim, was married to Gen.
Vicente Lim. As Minerva Laudico narrates: "You will remember that General Lim then was ranking in the Philippine Army, and therefore, he had to make many provincial inspections, so we used to keep track of his schedule and write the clubwomen that General Lim would be there. So Mrs. Lim would be there to organize the women, etc. One day whar happened was, a streamer said, 'Weicome to Mrs. Lim and Party.' So poor General Lim became the party of his wife. But he did not mind." 14 Laudico hastens to explain that this did not mean he was "under the saya" - an expression loosely translated as "dominated by his wife," saya being a woman's skirt. It simply meant that he was secure and supportive of what his wife was doing to promote the political rights of women.

Impressed by the vitality of the suffrage campaign, even President Manuel L. Quezon, the most influential, albeit chauvinistic, Filipino leader at the time, wholeheartedly endorsed the women's cause. When Quezon's full support of women's suffrage was publicly announced, ocher politicians, even those who opposed it, "ceased their vociferations" and even worked vigorously for the success of the plebiscite "simply because of their desire to please the chief executive. ${ }^{15}$

While middle- and upper-class women were occupied with the struggle for the vote, their counterparts in other sectors were making their own contributions to Philippine sociery. According to the 1918 census, 696,699 Filipinas were engaged in "industrial pursuits." They constituted 26 percent of the total female population fourteen years of age or older who were employed in gainful occuparions $(2,690,331)$. The figure of 696,699 included women who worked at home, for textiles and clothing were still made by piecework; one source lists weaving, dressmaking, embroidery, hatmaking, and shoeand slipper-making as domestic manufacrures. 16 Housewives augmented their family income without going out to work.

Those who worked outside the home were employed by distilleries and laundries and by garment, paper, glass, candy, hemp, tobacco, tood, beverage, handicraft, and jewelry makers. They 
also operated dormitories and worked in pawnshops, bakeries, and business firms dealing with transportation, real estate, and the embroidery of native attire; in some cases, women were the managers of the firms. A 1930 survey showed that as many as 3,721 women were employed in cigar factories, which were concentrated in $\mathrm{Ma}$ nila. Another $\mathbf{5}, 000$ worked in other industries. They joined labor organizations for "mutual protection and benefit." These "mutual benefit societies" were loosely referred to as unions, although they were not such in the Western sense of the word. In 1931 there were twelve such unions, with a national female membership of 5,266-a significant number in the early labor movement in the Philippines. ${ }^{17}$

Wages were most often the issue that motivated women workers to join strikes and mass actions. The highest weekly wage was 16 pesos (U.S. \$8) and the lowest, four pesos (\$2). Women's wages varied according to skill and type of work. Some women were paid at a piece rate, and others at a daily rate. The need for better working conditions was another major issue. Some tasks required women to remain standing for long hours, if not for their entire working period. There were no separate lavatories and closets for their use. Lighting, ventilation, and sanitation were dismal in many of the factories. Nor were there adequate provisions for disability and health benefits. Health services while on the job were minimal, if not altogether lacking.

In time, many of these issues were addressed and resolved, owing in part to pressure from the labor organizations. By 1933 the Philippine legislature had passed an important law limiting working hours in factories to only eight a day. Several factories had instailed better facilities for the health and well-being of their workers.

Women were also active in social movements directed against U.S. colonial rule. In spite of the existence of a sedition law banning nationalist activities, a number of uprisings against the U.S. authorities took place. One of these, the Sakdal (meaning "to accuse, complain, or protest") movement peaked on 2-3 May 1935, when in three Tagalog provinces the Sakdalistas launched a series of uprisings against the Philippine Commonwealth. They wanted "immediate, complere, and absolute freedom" because they realized "that no other kind of freedom can be conducive to the political, economic, and social salvation of the Filipino people. ${ }^{n 18}$

One of the major Sakdalistas was a womanSalud Algabre (later Generalla), a tenant on a landed estare in Laguna Province. She considered the government unjust and abusive: "The needs of the laborers were ignored. The leaders paid no attention to the people."19 Just before the first uprising on 2 May 1935, Algabre was given the rask of telling key rebel leaders in each town to organize the people "to march to their municipal buildings, capture them, raise the Sakdal flag, and proclaim independence." The Sakdalistas only had bolos (oversized native knives), clubs, sickles, and a few shotguns and pistols for weapons. On the first day of the uprising Algabre's husband, Severo, took charge of capturing the Cabuyao municipal building while Salud led another group to the highway. "We felled several trees across the road. It must have been about six o'clock in the evening when we began to stop the traffic." Although the rebellion failed, Salud Algabre never regretted her Sakdal involvement. Several years later she recalled May 1935 as the "high point of all our lives." 20

Thus, the period trom the beginning of the century to the outbreak of World War II was a moment of history for women in the Philippines. They were launched into a new world altogether after centuries of enforced domesticity, illiteracy, and cruel repression under Spanish rule. Possibilities heretofore denied women were opened up during the four decades prior to the war; more than that, the taients and energies of Filipinas were engaged in a political way. They became not just socially but also politically aware. Presentday feminism in the country draws much of its vitality from this earlier period of political engagemene, which transformed the traditional world of Filipinas. A new consciousness evolved from their involvement in the sutfrage movement, labor unions, and nationalist movements. Athough they differed greatly along class lines, 
they were brought together by changes in Philippine sociery and the new or expanded roles for women in it.

\section{THE POSTINDEPENDENCE YEARS}

During World War II the Philippines was occupied by the Japanese and became a fierce battleground. By the end of the war the country was almost totally devastated physically, economically, and psychologically. But women-having gained the vote and political experience-were prepared to function in the postwar government that was consolidated by the national elections in April 1946 and the proclamation of the independent Philippine Republic on 4 July of the same year. Remedios Fortich from Mindanao and Geronima Pecson from Luzon were the first women elected-to the Lower and Upper Houses, respectively-in the new independent government. From 1946 until 1971 (the last vear of free elections before the declaration of martial law), 11 women were elected representatives and 7 , senators. During the same period 6 women were elected governors (heads of provinces) and 2, ciry mayors. A good number were elected vicegovernors, members of provincial bourds (legislatures), city and municipal maỵors, vice-mayors, and council members.

But in Philippine politics betore 1971, this record was not enough to make a dent in the male-dominated circles of political power, even though women voters outnumbered men voters. Statistics from the Commission on Elections show that in eight out of eleven elections during this period, more women than men turned out to vote. ${ }^{21}$ Nonetheless, Filipinas never got together in substantial numbers to support women's issues or women candidates. Their political organizing ivas weak, particularly during the immediate postwar period, when women were largely preoccupied with reconstruction efforts in their houses and lives. Moreover, politics was still seen as a man's domain, and women voters were not necessarily voting as women. In 1951 an attempt to organize a National Political Party of Women to consolidate th.e women's vote never got off the ground. ${ }^{22}$ Instead, in the same year a separate group launched the Women's Magsaysay-forPresident Movement to support the presidential bid of Ramon Magsaysay. ${ }^{23}$

By the late 1960s and 1970s a new generation of Filipino women had emerged, less conservative than their parents in social and political orientation and more inclined to new and progressive ideas. They were marrying later and having fewer children, and greater numbers were choosing to remain single. These changes were more visible among urban-based, educated middle- to upper-class women-in short, among well-off professionals. Many women were also leaving for abroad, mostly to the United States, to take jobs or pursue graduate studies.

Philippine politics itself, though still controlled by elite interests, was also undergoing significant changes. The bourgeois political system, highly dependent on U.S. military and economic assistance for survival and embroiled in corruption over the years, was being challenged by new forces in sociery. ${ }^{2+}$ The underground left won adherents among the young, and student activ. ism intensified, particularly at the University of the Philippines, long known for nurturing a liberal tradition in education. The newly reestablished Communise Party of the Philippines joined with the New People's Army in 1969 and set up guerrilla-operations zones in major regions of the country. At the same time, the Muslim secessionist movement gained momentum. With the government increasingly threatened by communist and Muslim insurgents in the provinces and by a declining economy, President Ferdinand Marcos declared martial law on 21 September 1972. Marcos was no longer eligible for a third presidential term under the constitution, and the only way he could cling to power was by installing a dictatorship.

The excesses and repression of the Marcos regime drove more and more young people underground. Newly graduated Filipinas and women students joined the cadres of the New Reople's Army in increasing numbers to participate in mobilization work in the provinces. These women, primarily from middle-class backgrounds, left the 
comfort of their homes for an uncertain, if not dangerous, life in the hills. Their tasks in the movement were not much different from the men's. As Clarita Roja (a pseudonym) wrote in a letter from the underground, all "comrades" were expected to conduct political work among the masses and among themselves. "Household chores [were] rotated, assignments going to men and women alike." 25

At the forefront of the women's struggle during this time of political upheaval and social ferment was the Malayang Kilusan ng Bagong $\mathrm{Ka}$. babaihan (Free Movement of New Women), whose acronym, MaKaBAKA, stood for "dare to struggle." It was organized by Maria Lorena Barros, a militant student leader who led the first mass action-picketing the Miss Philippines Beauty Pageant in April 1970. MAKrBAKt activists, clearly advocating a Marxist ideology, also did organizing work among the women in factories and barrios. The underground network distributed clandestine publicarions and sent them to supporters in the United States and other countries either by mail or by courier. MLAkiBakA is described in a mimeographed publication entited Filipino Women in the National Liberation Struggle, probably written shortly after martial law was declared in 1972: "Although the membership of MAKIBAKA in its early beginnings was comprised of students, young protessionals, and other sectors of the urban petty bourgeoisie, efforts to promote the national democratic line necessitated the incorporation of women of the working class. Women took to the streets to participate in mass actions, established cottage industries, and formed women's associations to set up day care centers not only to educate the children but to politicize the mothers."26 MAKIBAKA's platform was considered too radical by other women's groups, which were more moderate in their demands or more oriented to reforming existing institutions than to dismantling them altogether.

Barros, who worked as an Nra cadre in South. ern Luzon, was caught and murdered by government soldiers in 1976. Although the movement that she headed funcrioned within the CPP-NPA framework, it is difficult to label it Marxist or radical feminist, for it combined elements of both. In Barros's words: "The Filipina, through her militant participation in the revolutionary struggle, has brought to life a new woman. This new woman is no longer a mindless ornament (which she would be if born to a well-to-do family), or a mindless drudge (which she would be if she were the wife or daughter of a peasant or worker). She is a woman fully engaged in the making of history, in the destruction of imperialism and feudalism, and the building of a new society. No longer is she simply a woman-formarriage; more and more she is a woman-foraction. A comrade." 27

As the women in the NPA and the MAKIBAKA activists were advocating armed revolutionary struggle, another group of women, inspired by the "theology of liberation," openly defended human rights and exposed military abuses. Called religious radicals or the Christian left, these nuns and lay supporters monitored the arrests of suspected "subversives," made representations with military authorities regarding the disappearance of political activists, helped to rehabilitate released political prisoners, and organized the urban poor. Some of them lived in the slums, devoting themselves to work that they called conscienticization-an attempt to raise the consciousness of the poor and disadvantaged, particularly with regard to assercing and protecting their rights. The activist nuns were instrumental in forming various organizations, the best known of which was the Association of Major Religious Superiors of the Philippines, which documenced the arrest, torture, and release of political prisoners in a publication entitled Philippine Human Rights Update. This organization aiso provided data to international human rights organizations like Amnesty International on the abuses of the Marcos regime.

A leader of the religious radicals, Sister Mariani Dimaranan of the Franciscan order, was arrested in October 1973 and detained by the military as a subversive for, 47 days-anyone who opposed the government was called a subversive. Sister Mariani headed a group called the Task Force 
Detainees of the Philippines, which recorded the torture or "salvaging" of political prisoners and of detained underground activists. Salvaging was a term used during the years of martial law to describe the summary execution of radical activ. ists in the military camps and in places known only to the military. Sister Mariani's detention did not deter her from denouncing the Marcos regime and the Philippine armed forces in later press interviews. ${ }^{28}$ In 1983, the tenth year of task force activities, Sister Mariani said that the organization had helped thousands of detainees. "We are very clear about our purpose. We help victims irrespective of their ideology. 'Komunista man o hindi, may karapatan yan' [Whether Communist or not, he or she has rights]." 29

Another activist nun, Sister Christine Tan, was also arrested for subversion for her work in the campaign to terminate the agreement allowing U.S. military bases to operate on Philippine territory. She worked and lived in the slums-and still does. Like Sister Mariani, Sister Christine sought audiences with military authorities on behalf of political detainees and their families. She also petitioned the Supreme Court to abolish Marcos's detested Presidential Commitment Order, under which any citizen could be detained without legal charges.

Not Sister Christine alone but groups of women, in cooperation with their male counterparts, opposed the U.S. bases in the Philippines. The bases-a colonial legacy-were a sore point in Philippine-U.S. relations that antedated martial law and that was exacerbated by U.S. government support for Marcos up to the very end of his stay in power. In fact, the phrase "U.S.-Marcos dictatorship" was used to draw attention to the role of the United States in propping up the regime.

A militant women's group, General Assembly Binding Women for Reforms, Integrity, Equality, Leadership, and Action (GABrreLA)which drew its name from Gabriela Silang, the eighteenth-century rebel leader-spearheaded the movement against the bases. Formed in 1984 out of several organizations across the country, GABRIELA'S membership grew to 50,000 in 1985-cutting across social, economic, reli- gious, and ideological boundaries. But the more articulate and militant members advocated a hard-line anti-U.S., anti-imperialist position. Along with other radical groups, GABRSELA's most common activity was picketing the U.S. Embassy in Manila, carrying streamers or signs with messages like "Down with the U.S.Marcos," or "U.S. bases, time to go." The rallies were generally peaceful, but the police occasionally arrested protesters. The most prominent GaBruela leader, Nelia Sancho-a former Miss Asia-Pacific beauty queen - was arrested and detained by the Marcos regime for several months in the late 1970s. In the same period, another Gabrrela leader, Maita Gomez, fled to the hills and joined the resistance.

Another major bases-related activity was the teach-in, organized to educate people, especially students, about the history of the bases, about issues in Philippine-U.S. relations, and about the evils that military base economies spawnedincluding prostitution, gambling, drug pushing, gunrunning, the exploitation of local residents, killing, and ocher forms of violence. But the main point that women emphasized was that the continued presence of the bases was an affront to Philippine sovereignty-living symbols of an oppressive colonial past.

The issue of prostitution has to be seen in the context of the U.S. military bases and the Marcos government's acceleration of tourism as a source of foreign exchange. The bases have served as magnets, drawing women to prostitution our of poverty and desperation. It is not known exactly how many women are engaged in the trade in the Clark and Subic areas, but 30,000 would not be an unreasonable estimate. They come mostly from depressed farming, fishing, or industrial areas in the Bicol or eastern Visayas region and are typically young (between 18 and 20 years old). The prospect of earning money that they could then send to their families in the provinces, the possibility of going abroad if they are lucky enough to marry U.S. servicemen, and the simple attraction of city life are some of the pull factors that bring many of these women to prostitution at the bases and urban centers. 
The Marcos regime exacerbated the problem of the flesh trade by vigorously promoting "sex tourism" to earn dollars for the ailing Philippine economy. In government policies prostitution was euphemistically referred to as "the hospitality industry." The women were presented as "hospitality girls," "a-go-go dancers," "hostesses," and "masseuses." The Ministry of Tourism regularly conducted sex tours for male visitors, and child prostitution was promoted for pedophiles. Pedophiles were taken directly to Pagsanjan, Laguna Province, which earned the disgusting distinction of being the pedophile capitai of Asia. The mail-order-bride business targeted men from the United States and Australia who were looking for wives. The exploitation of women and children reached shameless proportions during the Marcos dictatorship. Never before had Filipinas been so degraded.

The ensuing public outrage was mainly the result of efforts by women's organizations to expose the scandalous operations of the Ministry of. Tourism and its allies. The Third World Movement Against Exploitation of Women conducted a media campaign to denounce the hospitality industry, projecting the prostitution issue as symptomatic of the basic problems of Philippine society-particularly poverty and the traditional exploitation of women. Any attempt to reframe the issue of prostitution, the organization argued, would be diverting the issue. "Such treatment is not much different from prescribing aspiin for meningitis. ${ }^{n 0}$

The Center for Women Resources helped by documenting the extent of prostitution. "As of 1980 , there were about 120 flesh shops in Manila's tourist belt, 21 of which were accredited by the Ministry of Tourism and licensed by City Hall. Each shop had 80 to 200 giris employed by accredited tour agencies." 31 In regard to the bases, the center repeatedly made a comparison with Saigon, which had 400,000 prostitutes by the time the Americans left in 1975: it had become a city of prostitutes and pimps. Other women's organizacions concentrated on the issue of dislocation should the bases pull out: Where would the no-longer-employed women go? 32
The repression of human and democratic rights by the Marcos regime and the continuing abuse of the population by its instrumenes, particularly the military establishment, clearly had a radicalizing effect on many women's groups in sociery. Another example of how women courageously defied the authoritarian practices of martial law was in the Philippine media. One of the first casuaities after the imposition of martial law was freedom of the press. Several of those arrested after Marcos shut down the media in 1972 were journalists, mostly male. Marcos cronies bought existing media to silence critics or set up new media to propagandize the regime. Censorship guidelines were laid down by the Print Media Council: criticism of Marcos and the first family was not allowed, for instance. But Philippine journalism has a long tradition of freedom of expression, which the regime could not eradicate. It took a woman, Ma. (Maria) Ceres P. Doyo of Panorama magazine, to test the limits of press censorship under Marcos. ${ }^{33}$

Dovo exposed the murder of a Kalinga tribal leader, Macli-ing Dulag, who led the resistance against the construction of the Chico River Dam project financed by the World Bank. After she wrote a piece on Dulag's killing in 1980, she was interrogated and warned by the military. Panorama's editor, Letty Jimenez Magsanoc, another woman journalist, supported Doyo and in turn wrote an article criticizing the "phony" lifting of martial law in 1981. The publisher of the magazine, under pressure from the regime, asked Magsanoc to resign. Instead of cowering, three more women journalists concinued their criticism of the regime. Ariene Babst, Sylvia Mayuga, and Niñez Cacho-Olivares-all Bulletin Today columnists-openly deplored the intimidation of their collengues and the perpetual military atrocities against the people.

"Sensing that these writers were creating a strong impact among the readers, the National Intelligence Board (NrB) under General Fabian Ver, Marcos' Armed Forces Chief of Staff, 'invited' eight women journalists for a 'dialogue.' $3+$ From December 1982 to January 1983 the board called in Babst; Olivares; the sub- 
sequent Panorama editor, Domini Torrevillas Suarez, and the staffer Lorna Kalaw-Tirol; Eugenia D. Apostol, the courageous publisher of Mr. and Ms., another magazine critical of martial law; Doris Nuyda, also of $M r$ and Ms; and JoAnn Maglipon of Bulletin Today. The military sued them for libel, and they promptly fought back. Babst, a member of Women in Media Now (wOMEN), an organization originally set up to publish works by women writers, filed a case before the Supreme Court to stop General Ver and his intelligence agents from harassing women journalists. The move was a bold one, leading to pressure to dismantle the military's Special Media Committee, which had undertaken the writers' inquisition. "It was a signal victory for press freedom, particularly for the women journalists of WOMEN who broke the complacency and sycophancy of the then brow-beaten media." ${ }^{35}$ Space does not permit going into the backgrounds of these journalists, who are still active in Philippine media circles. But collectively they recall the Katipunan women and the "suftragettes" who forged a brave new world in Philippine society.

\section{THE AQUINO ASSASSINATION AND FEMINIST MOBILIZATION}

The brutal assassination of the opposition leader Sen. Benigno dquino, Jr., by the Philippine military on 21 August 1983 was the proverbial straw that broke the camel's back. It unieashed a fury among the people that probably surpassed that of the 1896 revolutionaries. Millions poured into the "Parliament of the Streets"; they denounced the assassination and clamored for Marcos to step down. Remarkably, violence did not erupt even though the people were seething with rage. They did not want to provoke a military reprisal. They kept up the pressure on the regime by political mass action and alliance building among key organizations.

Women were in the forefront of postassassination politics. By this time they had created formidable alliances with other organizations that had been protesting the increasing militarization, hu- man rights violations, repression of civil liberties, and government corruption. Because the economic situation was so dire, family incomes had shrunk to the point where even the heretofore apolitical middle class began to complain. Women, who feit the crunch the most, took to the streets. They joined their more politicized sisters in the nearly 200 mass actions that took place between August 1983 and April 1984 after Aquino was laid to rest. Thus, women from all classes and persuasions worked side by side in challenging the dictatorship. Society matrons in their high heels walked alongside urban poor women in their sneakers or slippers in antiMarcos demonstrations. As they marched in the streets, women in offices threw yellow conferti from high-rise buildings to signify their solidarity with the protesters. The slain Aquino was to have been welcomed home on 21 August with a display of yellow ribbons. ${ }^{36}$

The involved organizations with the most members were GABRIELA and Karipunan ng Bagong Pilipina, or K+BAPA (New Filipino Women's Association). GABrIEL-t, which took shape in the protest movement against the Marcos regime and became a formal organiza. tion in 1984, had mostly urban-based and college-educated women for members. At its first general conference in March 1985, 71 organizations endorsed the GABRIELA manitesto, which called for advancing the women's liberation cause, uniting in the fight against poverty and terrorism under the Marcos regime, exposing the sexual abuse of political prisoners, and dismancling the U.S.-Marcos dictatorship. ${ }^{37}$ Their red banners with anti-imperialist slogans made them highly visible in demonstrations.

In July 1985, GABRIELA sent a large delegation to the U.N. International Decade for Women Conference in Nairobi to present a special report on militarization during the Marcos regime and its effects on Filipinas. "Many women detainees have been abused in the course of tactical interrogations, either as a form of reprisal for their involvement in anti-government activities or as a means of ferreting out intormation on such acrivities," said the report. ${ }^{38}$ The Gabruela delega- 
tion also joined a march taking place on the conference grounds to protest the violation of human rights, apartheid, corruption, and other ills in countries ruled by dictators.

Another umbrella organization, largely composed of farmers and other rural women, was also active in political work. Founded in March 1976, KABAPA focuses on issues of economic and legal equality for women and supports broader con. cerns: genuine agrarian reform, nationalization of key industries, restrictions on multinational corporate profits, and withdrawal of the U.S. military bases. 39

KABAPA, which has a national membership of 25,000 women, considers its consciousness. raising work among rural women its major achievement and has developed a packet of question-andanswer material that is used in seminars, workshops, study meetings, and role-playing sessions in local communities. The organization concentrates on consciousness-raising as a way to enable rural women-who belong to the 58 percent of the population living in the countrysideto fully understand the connection between their enduring poverty and the elite social structure. As long as they are exploited by the wealthier and more powerful forces in Philippine sociery, concepts like democracy and equality have no meaning. They will continue to be dependent on the meager resources accorded to them in the highly unequal economic distribution system. To break the pattern, they have to recast their traditional way of thinking and rely on themselves. In short, according to KABAPA, rural women's oppressed status can be rectified to a certain degree by political education, and this must start with selfreliance.

The question has been asked, Why are there so many women's organizations in the Philippines? One observer counted 171 organizations in metro Manila alone. ${ }^{40}$ In view of the geographic, regional, ethnic, religious, class, ideological, and other distincrions in Philippine sociery, groups of or about women are bound to proliferate. Significantly, in spite of the diversity and differences in perspective, there is a minimum of friction among the various women's organizations. GAB-
RIELA has lost some of its initial members who were of a more moderate ideological persuasion than the leaders. Some of these less radical members have joined other organizations or set up their own. GABRIELA continues, however, to be the voice of militant feminism in the country.

\section{WOMEN AND THE 1986 REVOLUTION}

The acceleration of women's activity during the Marcos period and the heightened tension broughe about by Senator Aquino's assassination reached a logical conjuncture in the People Power Revolution in early 1986.+1 Played out in four days in February (the 22 nd to the 25 th) at the center of metro Manila's largest highway, Epifanio de los Santos Avenue, more popularly known as EDSA, it was probably the shortest revolution on record. $* 2$ Marcos had arrogantly called for a snap presidential election on 7 February 1986. The various opposition forces united into one and nominated Corazon C. Aquino, widow of the slain senator, to run against Marcos. The president's monumental cheating and use of violence to win the election signaled his final collapse. The showdown was precipitated by the defection of Defense Minister Juan Ponce Enrile and Armed Forces Chief of Staff Fidel Ramos on 22 February 1986. Two million Filipinos gathered at EDSA to force Marcos to step down. What had started as a military mutiny escalated into a people's uprising. Tanks and armored vehicles came roaring down from the military camps around the area. Although the potential for violence was extremely high, people power turned out to be a peaceful confrontation. Outwitted and facing the wrath of the people, Marcos and his family and associates fled under cover of darkness on the night of 25 February. The U.S. government facilitated his exile to Hawaii the following day.

A vivid image from that time of incredible upheaval was nuns and other women holding up rosaries, banners, and pictures of the Virgin Mary, icons of the Santo Niño (infant Jesus), and other religious objects while men braced their bodies against the tanks that were ready to roll 
an!time. The religious symbolism was powerful. It stunned and mystified the soldiers. A bewildered marine commander ordered the tanks to retreat. More significantly, the leaders of the various military commands and their troops cast their lot with the people. Four days of quiet mage and courage ousted a formidable dictator, and EDSA is enstrined as the Filipino contribution to the theory of modern revolutions.

The women took part in the whole gamut of activities during the revolution. The nuns were the first to answer Jaime Cardinal Sin's frantic calls for peopie to proceed to EDSA and give support to Enrile and Ramos.. He called the Catholic church convents to send nuns to EDSA. One could argue that the religious women were responding out of obedience to cheir superior, but considering their long years of struggle against martial law, they could noc have passed up the moment that portended the end of the Marcos dictatorship.

Women of all classes-affluent Makati matrons, journalists, poor urban workers, faculty and students from public and private universities and colleges, vendors, and tactory workersmassed at EDSA during the tour days and nights. Those who could not be at the site prepared sandwiches and refreshments, and those who lived around EDSA made their residences available for people's personal needs. The media heroine June Keithley continuously broadcast instructions and messages over Radyo Bandido, which was transmitting from a clandestine station to escape military detection. Without her expert monitoring and forceful guidance over the airwaves, there might have been large-scale confusion about what was going on.

Women also negotiated with the soldiers not to roll the tanks or fire into the crowd. They brought food, water, cigarettes, cookies, flowers, and rosaries to the beleaguered soldiers, who were just waiting for orders from their superiors. It was a volatile situation. One stone thrown at the soldiers could have set off a bloody confrontation. The women negotiators appealed to the soldiers' sense of compassion and fear of God. The soldiers relented, and the tanks rolled back.
In sum, women played key svmbolic and practical roles in an unusual political upheaval that gave Southeast Asia its first woman president.

\section{PRESIDENT AQUINO AND THE POLITICS OF CLASS}

Corazon Aquino personified the bourgeois woman in Philippine society: descended from a weal thy landowning family in central Luzon with nineteenth-century roots in the Chinese mestizo class, she was proper in demeanor - a product of convent schools-and educated in the United States. Even though she operated in a political milieu-her father having been a legislator and her husband a politician for all of the 28 years that they were married-Aquino was not a public person. She was extremely reluctant to face Marcos in the 1986 election because she thought that as a "housewife" she did nor know anyehing about politics. She had never worked for a living, much less held public office. To appease her supporters, she said (probably not seriously) that she would face Marcos only if 2 million signatures could be gathered urging her to run. Her supporters, many of them women calling themselves Cory's Crusaders, were fervent about her running. They scoured metro Manila and the nearby provinces to collecr the 2 million signatures. Aquino herself went into deep meditation and said afterward, "We had to present somebody who is the complete opposite of Marcos, someone who has been a victim. ${ }^{13}$ The rest is history. Emerging from her quiet private world, she crisscrossed the country and caught the imagination of voters from all waiks of life. Her popularity during the campaign period and after EDSA is unequaled in the annals of Philippine history.

But her popularity has been diminished by a series of coup attempes and by an inability to exercise decisive leadership-which is needed in a sociery racked by poverty and inequality. Sorely lacking in political experience when she assumed office, Aquino was slow to exploit the potential of people power. For more than a year, from March 1986 to April 1987, during which she could have launched bold initiatives, such as land reform and 
a thorough cleanup of the military and bureaucracy, she instead chose to wait until the formal structures of government, including a new constitution and an elected Congress, were in place. Perhaps she failed to appreciate and understand the meaning of the revolutionary siruation created after Marcos's downfall. Yet to move toward dramaric reform was not easy, either, because the military and other instruments of authoritarian rule remained.

During the delay, Aquino's ruling coalition began to disintegrate. Enrile and his supporters plotted to oust her, and Mareos loyalists demonstrated in the streets. The New People's Army acquired the capacity for urban terrorism and continued guerrilla operations on the countryside as well. The Moro National Liberation Front went back underground after a proposed peace settiement with the Aquino government failed. Peace talks with the National Democratic Front, the umbrella organizacion that includes CPP-NPA, collapsed, and a new threat developed as the right-wing faction of the military establishment, the Retorm the Armed Forces Movement, engaged in several destabilization efforts.

In June 1990, stung by her deteriorating popularity, Aquino launched a political movement of her own-Kabisig, meaning "arm-in-arm" in Tagalog. According to her, Kabisig is not a political party. It is a movement designed to harness the support of the people for various development programs, especially in depressed provinces. With this program Aquino is doing what many supporters teit she should have done when she assumed power in 1986. Her critics see this as "too little, too late," bur others view it as an attempt to recover the people's support.

Some argue-though not openly for fear of being labeled sexist-that Aquino's indecisiveness on weighty issues of state may be attributed to her being a woman in a political world still dominated by men. This does not seem to be the case, for she has stood her ground on many occasions, unfazed by crisis and criticism. Perhaps fatalistic, she has been known to say, "Kung darating ang panahon mo, darating ang panahon mo" (When your time comes, it comes).t+
The Filipino academic and intellectual Francisco Nemenzo offers a differene view of Aquino's political style, arguing that her indecisiveness stems from a fear of confronting either the native elite from whose ranks she comes or the U.S. government: "She has desisted from tampering with structures other than those directly linked with Marcos." 45

It is too soon to judge the Aquino presidency, but it does appear to embody a politics of class that goes against some of the tenets espoused by feminism: equality and the empowerment of women, for example. Only one of more than 20 cabinet members is a woman-a fact that says much about the Aquino presidency's agenda on women. This lone woman cabinet member's position covers a field traditionally assigned to women: social work and development.

\section{CONCLUSION}

The participation of women in the nationalist movernent against Spain in the nineteenth century and their protracted struggle for female suffrage in the early decades of this century resulted in their deeper political consciousness. Women's militant opposition to the Marcos regime and their mobilization efforts during the tumult of the Aquino assassination and the EDSA revolution were more recent landmarks in the history of feminism in the sociery.

Philippine feminism has been discussed here as though it were singular, but it is actually a plural phenomenon-a mixed bag of social, economic, and political women-related initiatives on both the ideological and the practical level. Not one but several women's movements have taken place. These have been influenced by developments in other parts of the world, such as the struggle for women's rights and later the consciousnessraising activities of feminist groups in the United States; yet they have their own unique characteristics. Some have followed a specific ideological tendency; others have been guided by the larger issues that Philippine society as a whole has had to confront. I have thus examined the role of Filipino women in a broader social and political context, 
rather than in terms of the more specific malefemale structure of the society.

Philippine sociery is undergoing a period of redemocratization following two decades of authoritarian rule. The major problems of government corruption, a huge foreign debt, divisive. ness in the population brought about by the continuing presence of the U.S. military bases, insurgencies, and unrelenting poverty remain, however. Much has to be done. Women's groups must deal with these societal issues, as well as with the more specific concerns that affect them, such as child care, reproductive rights, male violence, discrimination in the workplace, sexual harassment, prostitution, and heaithcare. Philippine feminism is no longer a matter of expanding women's roles, as in the previous century; indeed; women now have many roles to play and much to do. The question is, How they can accomplish all these things, in addition to competing more successfully with men in the public sphere?

\section{NOTES}

1. Muslims, 4.3 percent; Protestants, 3.1 percent; Aglipayan, 2.8 percent; cultural minorities, 1.7 percent; Iglesia ni Kristo, 1.6 percent; Buddhists, 0.1 percent; and others, 4.3 percent. The percentages were calculated on the basis of the 1991 population of 60 million by Pedro S. Achuregui, president of the Cardinal Bea Institute for Ecurnenical Studies, Loyola House of Studies, Ateneo de Manila Universicy, Quezon Ciry. The Nitional Census and Statistics Office figures only come up to 1970.

The words Philippine and Filipino are otten used interchangeably-e.g., Philippine culture, Filipino tood, Philippine politics. Filipino refers to people in general, Filipina to Filipino women. Filipino is also the national language, declared so in the constitution of 1987. The language is largety based on Tagalog, spoken in Manila and the neighboring provinces. Its spelling was changed from Pilipino to Filipino in 1973 to make it more consistent with conventional usage and to be more national-it would evolve from the contributions of the different languages in the country, nor just from Tagalog.

2. The Treaty of Paris ceded the Philippines from Spain to the United States for U.S. $\$ 20$ million.

3. Unlike in the United States, poverty in the Philippines is not measured serictly by income per tour-person timily. It is more a qualitative concept, encompassing not only income levels bur also illiteracy, disease, nucrition, housing, and the availability of a number of amenitieshence the varying estimates.

4. See Fe C. Arriola, Si Maria, Lfoma, Gabriela, AtbpKuwentong Kasaysayan ng Kababaiban (Maria, Mema, Gabriela and others-historical accounts of women) ( $\mathrm{Ma}$ nila: GABRIELA and St. Scholastica's Institute of Women's Studies, 4 September 1990), 31.

5. Malolos, a historic town north of Manila, was the site of the revolutionary Congress convened by President Emilio Aguinaldo on 4 September 1898, three months atter the proclamation of Philippine independence from Spain.

6. This information was drawn from the Colegio de Sanca Isabel's historical marker, which still exists in Naga City. See Liceria B. Soriano, "Women and Educarion," in Yolanda Q. Javellana, ed., Woman and the Law (Quezon City: University of the Philippines Law Center, 1975), 81.

7. Fe Mangahas, "The Stanus of Filipino Women from Pre-Colonial Times to the Early .tmerican Period," in Pennie S. Azarcon, ed., Kamalayan: Feminist Writings in the Philippines (Manila: Bureau of Printing, 1928), 39.

8. Maria Paz Mendoza-Guazon, The Development and Progress of the Filipino Woman (Manila: Burenu of Printing, 1928), 40.

9. Encarnacion Alzona, The Filipino Woman-Her Social, Economic and Political Statzu, 1565-1937 (Manila: Benipayo Press, 1937), 67.

10. The more prominent ones were Pura Villanueva Kalaw (writer), Rosa Sevilla Alvero (educacor), Encarnacion Alzona (historian), Maria Paz Mendoza-Guazon (medical doctor), Pilar Hidalgo Lim (social worker), Joseta Llanes Escoda (social worker), Concepcion Felix Rodriguez (social worker, teacher), Natividad Almeda Lopez (lawyer, jurist), and Geronima Pecson (educator. senacor).

11. Guazon, Development and Progress, 45.

12. According to the 1939 census, the total Philippine poputation was $16,000,303: 8,065,281$ male $(50.4$ percenc) and $7,935,022$ female ( 49.6 percent), with $3,346,260$ (boch male and female) who were 20 years old and older. Because the total population was atmost equally divided benveen males and fernales, some 1,673,130 women would have been eligible to vore in the plebiscite on the basis of age. Bur literacy was also a requirement; and applying the 49 percent literacy mee to the total number of women eligibte to vote on the basis of age gives only 937,208 . Therefore, 300,000 would be 32 percent of 937,208 , the total number of women eligible to vore in the plebiscite. Acrually, the number would be slighriy lower, for the census-based figure includes 20 -vear-old women, who were one year short of voting age.

13. Alzona, Filipino Woman, 106.

14. Minerva Laudico, "Testimonies from Sutfragertes," in Women's Role in Philippine History-Papers and Proceedings of the Conference Held on 8-9 March 1989 
(Quezon Ciry: University of the Philippines Center for Women's Studies, 1989), 75.

15. Aizona, Filipino Woman, 104.

16. Ibid., 129.

17. Ibid., 135.

18. Memorial (in Pilipino), a Sakdal document intended for transmission to the U.S. Congress on the issue of Philippine independence. See Benedicto S. Librojo, Jr., "An Episode in the Long Agrarian Saga of the MassesAn Anaiysis of the Sakdal Movement" (Undergmduate thesis, University of the Philippines, Diliman, Quezon City, 1990), 39.

19. Appendix D, "An Interview with Salud Algabre," in David R Sturtevane, Popular Uprisings in the Philippines, 1840-1940 (Ithaca, N.Y.: Cornell University Press, 1976), 290.

20. Ibid., 294-95.

21. Tecla San Andres Ziga, "Women in Politics and Government," in Javellana, ed., Woman and the Law, 76.

22. Tarrosa Subido, The Feminist Movement in the Philippines, 1905-1955 (Manila: National Federation of Women's Clubs, 1955), 54.

23. In the 1987 congressional elections, a small alliemale political party, Kababaihan Para Sa Inang Bayan, or KaIBA (Women for the Mocher Country), put up or sup. ported women candidaces. Ana Dominique Coseteng of Quezon Ciry ran tor Congress under the KAIBA banner and won, but she was also endorsed by the por-Laban. kA18A also supported another congressional candidate, Venancio T. Garduce of Samar Province, who also won. The party became largely inactive after the election.

24. The term bourgeois is not used here with its classic European meaning of a mercantile or shopkeeping middle class that sprouted from a disappearing feudal society. The Philippine usage reters to those who made their forcunes after the Second World War. Unlike the old aristocracy, the newly rich, pejoratively called burgis (a Filipino corruption of bourgeois), tend to flaunt their wealth, illgotten or otherwise, and affect the lifestyle of high living, respectability, and culture of the original bourgeoisie. Many entered the political arena after the war and have maintained their power or influence.

25. Clarita Roja, "Leteer to Mrs. D——" (July 1973). After many years it was revealed that Mrs. D- was Delores Feria, an English professor at the University of the Philippines who supported radical causes and was underground hexself in the early 1970s during martial law.

26. Editorial Collective, Philippines Research Center, Filipino Women in the National Liberation Struggle (1972!).

27. Ma. Lorena Barros, "Liberned Women," Ang MaLaya (13 March 1971), 3, as quoted in Editorial Collecive, Filipino Women in the National Liberation Struggle, 3.

28. See Robert L. Youngblood, Lareos Against the
Church-Economic Development and Political Repression in the Philippines (Ithaca, N.Y.: Cornefl University Press, 1990), 162.

29. Ma. Ceres P. Dovo, "The Sisters Have Come a Long Way," Philippine Panorasna 12, no. 22 (29 May 1983): 18.

30. Ma. Ceres P. Doyo, "The Prostitution Problem Must Be Viewed from a National, Even Global, Perspec tive," Philippine Panorama 12, no. 22 (29 May 1983): 38.

31. Ibid., 40 .

32. Another organization, Campaign for a Sovereign Philippines, headed by Ma. Socorro Diokno, expressed a similar concern for the women who would be dislocated if the bases were pulled out. "We have been looking into the possibility of putring up cotrage industries within the bases and also of alternative education for the women involved." There would be initial dislocation, bur if the women were given a chance to do something better and certainly less demeaning than prostitucion, they would "knock on it," according to Diokno. See The US Military Bases and the Filipino Women-Women's Discousse, No. 1 (Quezon City: Center for Women's Resources, 1989), 11.

33. Aurora J. De Dios, "Participation of Women's Groups in the Anti-Dictatorship Struggle: Genesis of a Movement," in Women's Role in Philippine History, 101.

34. Ibid.

35. Ibid.

36. It is not possible to mention all the women's organizations whose members filled the streets, but among the major ones were Kilusan ng Kababaihang Pilipino, or PILIPINA (Filipino Women's Movement); Samahan ng Babaing Nagkakaisa, or SAMAkANa (United Women's Associacion); Katipunan ng Kababaihan Para sa Kalayaan, or uKK (Women's Association for Freedom); Samahan ng mga Mag-aaral na Kababaihan, or Samaka (Federation of Women Students); Kapisan ng Madre ng Kamaynilaan, or Enlar (Association of Religious Women in Metro Manila); Women for the Ouster of Marcos and Boy. cott (WOMB); Mothers and Relatives Against Tyeanny (MARTYR); Alliance of Concerned Women for Reforms (AWARE); Concerned Women of the Philippines (CIVP); Associacion of Women in Theology (AWTr); National Association of Religious Women in the Philippines (Now); Women in Media Now; GarRIELA, then in its formative stage; and Katipunan ng Bagong Pilipina, or Kabara (New Filipino Women's Association).

37. GABRIEL4, Convention Proceedings (Quezon City, Mt. Carmel Community Center, 2-3 March 1985), 19.

38. GABRIELA, Pence Is an Illusion-hilitarization and Its Effects on Filipino Women, a Special Report (Ma. nila: GABRUELAt Women's Coalicion, 1985), 76.

39. Its basic mission is "To strive for tquality before the law in all fields where it does not exist; equality of eco- 
nomic rights, including the right to work and the right to equal pay for work of equal value, non-discrimination in employment opportunities and security of employment atter marriage, and equality of rights and responsibilities in the family and home." KABAPA Primer (Manila, 1976), 1.

40. Barbara Mahel, The Situation of Filipino WomenFocus on Women's Organizations Based in Manila (Manila: Friedrich Naumann Stiftung, 1987), 165-94.

41. Although people power is commonly used to describe the EDSA revolution, some observers think that the term sounds like the passive manpower and that the more appropriace term, people's power, has a more political meaning: "organized by the people and used by the people to advance their own interests." Ponciano L. Ben- nagen, "It's People's Power, Nor People Power," Midweek 1, no. 17 (26 March 1986): 30.

42. The highway is named after Epifanio De Los Santos, a Filipino writer who wrote patriotic articles in Spanish for La Independencia (Independence) in 1898.

43. Sandra Burton, Impossible Dream-The Marcoses, the Aquinos, and the Unfinished Revolution (New York: Warner Books, 1989), 302.

44. Belinda A. Aquino, ed., Presidential Leadership and Cory Aquino (Quezon City: University of the Philippines Center for Integracive and Development Studies, 1990), 26.

45. Francisco Nemenzo, "A Nacion in Ferment: Analysis of the February Revolution," in M. Rajaretnam, ed., The Aquino Altemative (Singapore: Institute of Southeast Asian Studies, 1986), 52. 
on behalf of the Women's Forum, a project that combines the efforts of the women's movement with those of women in public administration. In 1985 she ran for election to the Senate.

The Philippines

BELINDA A. AQUINO is professor of political science and Asian studies and director of the Center for Philippine Studies at the University of Hawaii at Manoa. She is the author of Politics of Plunder-The Philippines Under Marcos (1987) and the editor of Presidential Leadership and Cory Aquino (1990), The Failed December Coup (1990), and Reflections on the U.S. Bases in the Philippines (1990). She has taughe courses on women and politics in $\mathrm{Ha}$ waii and the Philippines and was instrumental in setting up the Center for Women's Studies at the University of the Philippines.

Poland

RENATA SIEMIENSKt is professor at the Institute of Sociology, Warsaw University. Her recent research and publications have centered on cross-cultural analyses of the value systems of different populations, the functioning of local leaders, and women's participation in public life. She is the author of Gender-OccupationPolitics: Women in Public Life in Poland (1990, in Polish) and Gender Inequality: $A$ Comparative Study of Discrimination and Participation (1990, written with Mino Vianeilo), as well as a number of articles on women's issues.

Puerto Rico

YAMILA AZIZE-VARGAS is associate professor at the University of Puerto Rico, Cavey, where she has directed the women's studies program, PRO-MUJER, since 1987. A specialist in literature, women's history, and women's health issues, she is the author of Women in Struggle (1985), a history of feminism in Puerto Rico, and the editor of Women in Puerto Rico (1987), an anthology of research essays; both are in Spanish. She received a Ford Foundation
Fellowship to pursue her graduate studies and holds a Ph.D. from the University of Pennsylvania.

\section{South Africa}

BARBARA KLUGMAN, a political activist and social anthropologist, coordinates the Women's Health Project of the Center for Health Policy at the University of Winvatersrand, Johannesburg. She was active in the anti-apartheid United Democratic Front, served on the executive board of the Federation of Transvaal Women, and in 1991 became chair of the Black Sash in the Southern Transvaal. Her research and publications concern women in connec. tion with trade unions, reproductive rights, and population politics.

Spain

MARIA TERESA GALLEGO MENDEZ, professor of political science and director of the Women's Studies Institute at the Autonomous University of Madrid, is the author of Women, the Falange, and Francoism (1983, in Spanish), the coauthor of The European Left (1985, in Spanish) and Violence and the Patriarchal Society (1990, in Spanish), and the editor of New Perspectives About Women (1982). She has contribured (with M. A. Duran) to The New Women's Mopement in Europe and the U.S. (1980) and (with C. Fernandez) to The Implementation of Equal Rights for Men and Women (1991). She has been active in the socialist feminist movement and in furthering ivomen's studies in Spanish universities.

Sudan

MAGDA M. EL-SANOUSt is assistant researcher and coordinator of the Documentation Unit for Women's Studies at Ahfad University for Women. Her specialties are women in politics, and rural and displaced women. She is the author of "The Effect of Socialization and Education on Women's Political Participation in Sudan" (1990) and "Displaced Women in Omdurman" (1990), both in Arabic. She is head of the Relief Aid Otfice of the Babiker

794 Contributors 